\title{
Olive Tree Leaves-A Source of Valuable Active Compounds
}

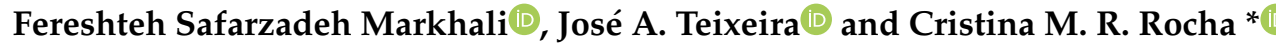 \\ CEB-Centre of Biological Engineering, University of Minho, Campus of Gualtar, 4710-057 Braga, Portugal; \\ id7987@alunos.uminho.pt (F.S.M.); jateixeira@deb.uminho.pt (J.A.T.) \\ * Correspondence: cmrocha@ceb.uminho.pt or cmrochainv@gmail.com
}

Received: 13 August 2020; Accepted: 15 September 2020; Published: 17 September 2020

\begin{abstract}
The agricultural and processing activities of olive crops generate a substantial amount of food by-products, particularly olive leaves, which are mostly underexploited, representing a significant threat to the environment. Olive leaves are endowed with endogenous bioactive compounds. Their beneficial/health-promoting potential, together with environmental protection and circular economy, merit their exploitation to recover and reuse natural components that are potentially safer alternatives to synthetic counterparts. These biomass residues have great potential for extended industrial applications in food/dietary systems but have had limited commercial uses so far. In this regard, many researchers have endeavoured to determine a green/sustainable means to replace the conventional/inefficient methods currently used. This is not an easy task as a sustainable bio-processing approach entails careful designing to maximise the liberation of compounds with minimum use of (i) processing time, (ii) toxic solvent (iii) fossil fuel energy, and (iv) overall cost. Thus, it is necessary to device viable strategies to (i) optimise the extraction of valuable biomolecules from olive leaves and enable their conversion into high added-value products, and (ii) minimise generation of agro-industrial waste streams. This review provides an insight to the principal bioactive components naturally present in olive leaves, and an overview of the existing/proposed methods associated with their analysis, extraction, applications, and stability.
\end{abstract}

Keywords: olive leaves; by-products; bioactive compounds; polyphenols; extraction; sustainability

\section{Introduction}

Olive tree (Olea europaea L.), a member of the Oleaceae [1], is a drought-tolerant plant essentially native to the Mediterranean climate [2]. It is universally planted in tropical and subtropical regions [3], predominantly in Greece, Italy, Spain, Australia, Portugal, France, Cyprus, Israel, Jordan, USA, Morocco, Turkey, and Tunisia [4]. The Mediterranean region, representing above $90 \%$ of the cultivated area, is estimated to be above 11 million hectares in 2017 [5].

The leaves of the olive tree are within easy reach either from the olive orchard or from the residues remained after agricultural [6] and industrial by-products [7]. The olive mill leaves constitute a relatively sizable portion, in the range of $4-7 \%$ [7], up to $10 \%$ of overall weight of processing olives [8] and account for almost $5 \%$ of overall yield from olive oil by-products [9]. During the horticultural system, a significant proportion of leaf residue is also generated. In the course of pruning, depending on variations in geography, horticultural routine, and tree lifetime, the amount of leaf by-products roughly accounts for $25 \%$ of total weight of pruned residue [10].

The increment of these residues represents a major problem through its adverse effect on environmental sustainability, as a large proportion of leftovers is underexploited and/or inadequately disposed of, e.g., through incineration [11]. There is an increased awareness that this underutilised biomass could be regarded as a valuable/health-promoting resource, if properly exploited, with great 
market potential in the food and dietary system. The principal benefits of olive leaves [7] are attributed to their distinctive molecular and biological properties [6] which confer protective activities of (i) antioxidation [12], (ii) anti-inflammation [13], (iii) anti-hypertension [1], (iv) anti-arrhythmia [14], and $(v)$ inhibiting low-density lipoprotein receptors [15]. Indeed the exertion of bioactivity stems from the action of intrinsic phytochemicals, particularly polyphenols [16], present in olive leaves [17]. In this respect, recovery of bioactive ingredients from this residual biomass and their conversion into value-added ingredients in the food and dietary system, helps promote a sustainable processing method to provide bio-based/nutritional products with a minimum/zero waste stream.

At present, commercial applications of olive leaves are mostly limited to (i) folk medicine, to protect body against chronic conditions such as cardiovascular disease and diabetes [7,18,19], and (ii) animal feed [6]. Research studies have now focused to determine broader applications of olive leaves across various industrial sectors including foods, modern medicines, and pharmaceuticals [19,20]. Although much effort has been made to extend the use of leaves from traditional to modern/industrial applications, the sustainable recovery of natural biomolecules comes with several challenges, which requires better performance to ensure (i) optimum extraction that is less time-consuming/economical, (ii) the stability of biomass and leave extracts, (iii) the safety and non-toxicity of outputs and inputs, (iv) the bioavailability of product, and $(v)$ up-scalability of the processing system. This review provides an outline of the principal endogenous bioactive compounds in olive leaves, their characteristics, with respect to their biological activities and industrial uses, and discusses the existing processing approaches/proposals for the recovery of these compounds.

\section{Bioactive Compounds in Olive Leaves}

Bioactive compounds are the naturally occurring ingredients derived from a variety of food crops [21]. They are grouped as either essential or non-essential components [22]. Unlike essential nutrients that are necessary for the human biological system - as the body is unable to synthesise them and their deficiency may bring about biological disorders-non-essential compounds are those which are not necessary for biological functions and their insufficient/lack of intake has no influence on physiological disorders [23]. However, the presence of non-essential groups in food crops, predominantly phytochemicals [23], are appreciably prized for their auxiliary physiological effects in promoting health to a further extent than those exerted by essential nutrients present in foods [21,22,24]. Of all the beneficial effects, antioxidative, anti-atherosclerotic, antimicrobial, and anti-inflammatory functions prevail in most bioactive compounds [21]. The processing methodologies involved in food functionalisation and nutraceutical supplements substantially determine the extent of (i) bio-accessibility, that is the liberation of bio-compounds from the cell walls of the food before being absorbed in the blood cells (ii) bioavailability, namely, the availability of active compounds for physiological activity/metabolism upon absorption, and (iii) bioactivity [25].

\subsection{Polyphenolic Compounds}

Polyphenols, a group of heterogenous compounds, refer to naturally occurring secondary metabolites largely found in plant species [26]. Their molecular structure is based on a linkage between hydroxyl groups (polar phase) and one aromatic ring [27]. The magnitude of antioxidation of phenolics [28] partly relies on the location and arrangement of hydroxyl groups [29]. It also depends on their presence/proportion in the food, and their molecular formation in the matrix, i.e., whether they are in free or bound state [30]. Research has demonstrated that the aglycone portion displays higher biological activity than the glycoside portion (aglycones bound to glycones) [30]. The free radical scavenging activity exerted by phenolics, can limit the initiation phase, and postpone the propagation phase of lipid oxidation, with the potential of minimising the production of volatile components from hydroperoxide degradation [31]. Polyphenols, together with displaying physiological activities including antioxidation, are organoleptically responsible for the flavour and colour of the foods. On this account, they are considered beneficial to promoting health and food quality [16,29]. 
Phenolics relatively have good stability upon stomach digestion but the level of bio-accessibility may vary depending on numerous decisive factors, such as (i) plant origin and physical structure, (ii) chemical composition of phenolics and their reaction with other active components released from the cell walls of the ingested foods, and (iii) processing methods/conditions [32]. The processing parameters include (i) heat treatment, and (ii) drying when a medium/low temperature is used (around $40-50^{\circ} \mathrm{C}$ ) which may adversely affect phenolic contents and bioactivity, that is attributed to the fact that the survived enzymes (that were not deactivated at low temperature) can bring about oxidative and/or hydrolytic reactions, and hence the degradation of phenolic constituents [33]. Heat treatment may be advantageous (through exerting solubility and liberation of phenolics from the food matrix, and/or developing disintegration of the cellular structure [33]). It can also be unfavourable, giving rise to degradation of the components that are unable to withstand thermal conditions [32].

Olive leaves are abundant in a range of known phenolic groups that are broadly clustered into (i) secoiridoids (including oleuropein and oleuropein-aglycone), (ii) flavonoids (such as rutin and luteolin-7-glucoside), and (iii) simple phenols (such as hydroxytyrosol and tyrosol). Of these, secoiridoids are characteristically present in the Oleaceae family that well applies to Olea europaea L. [34], have notably gained attention owing to their distinctive potential for biological activity [35]. Iridoids, usually with glycosidic structure in plants, derive mainly from monoterpenes [35]. The ring-breakage of cyclopentane gives rise to the formation of secoiridoids $[36,37]$ that are typically attached to glycosides and distinguished by the presence of elenolic acid linkage within their atomic arrangements [34].

Among the most typical phenolics in olive leaves include hydroxytyrosol, tyrosol, rutin, and oleuropein [6,14]. Indeed, oleuropein and hydroxytyrosol are detectably prominent in olive leaves. Oleuropein, a key component of secoiridoids in olive leaves [17] is characterised by an ester linkage of elenolic acid glucoside and hydroxytyrosol [34,38]. Because of its unique secoiridoid structure, it is organoleptically characterised by a strong bitterness [18]. The concentration of oleuropein in olive leaves has been reported to be in the range of 6 to 9\%, dry basis [39]. Bouaziz and Sayadi [40], in their research on evaluating antioxidant ability of olive leaves from Tunisian cultivar, observed that oleuropein ( $6.8 \mathrm{~g} / 100 \mathrm{~g}$ fresh leaves) was the principal phenolic constituent in the leaves of olive trees.

The protective attributes of oleuropein are reflected typically by their inhibiting effects against (i) oxidation [14], (ii) microbial disorders [14], (iii) inflammation [41], and (iv) platelet aggregation [14]. In addition, oleuropein is found to be effectively capable of re-building the tissue damage, caused by cisplatin in stomach and lung organs [42]. It is noteworthy that the phenolic concentration in olive drupes is comparatively as great as those in olive leaves [6], however the proportion adversely decreases during the maturation and processing steps. For example, significant depletion of oleuropein, during processing, is highly likely, particularly through enzymatic reactions [43] and de-bittering operations [44]. The degradation of oleuropein in olive processing further merits exploitation of olive leaves, as oleuropein is appreciably retained/unaffected in olive by-products. In principle, there are numerous decisive factors (Table 1), acting dependently or independently, that markedly determine the proportion, structural feature, and bioavailability of polyphenols in olive leaves.

Oleuropein aglycon, is liberated in the course of oleuropein de-glycosylation [45]. Research demonstrated that oleuropein aglycon has a great contribution to developing bitterness/astringency [46]. The health benefits associated with this compound include its ability to (i) curtail neurodegeneration, mainly through suppression of A $\beta 1-42$ toxicity [47], (ii) decrease low-density lipoprotein cholesterol [6], and (iii) promote oxidative stability of lipids [15].

Olive leaves, ubiquitous with flavonoids, are further valued for dietary applications. Flavonoids exert a favourable protection against carcinogenic, cardiovascular [48], and microbial [49] diseases. Typical examples of flavonoids in olive leaves are rutin, luteolin, and luteolin-7-glucoside [6,14]. Total flavonoids in olive leaves, on a dry-basis, using different extraction techniques were: (i) through maceration, $54.92 \mathrm{mg} / \mathrm{g}$ (with $80 \%$ ethanol) and $34.50 \mathrm{mg} / \mathrm{g}$ (with distilled water), and (ii) through sonication, $21.15 \mathrm{mg} / \mathrm{g}$ (with $80 \%$ ethanol), and $36.40 \mathrm{mg} / \mathrm{g}$, with distilled water as the solvent [50]. 
Hydroxytyrosol, largely found in olive leaves, is among the main simple phenolic alcohol [51]. The formation of hydroxytyrosol, derives from the hydrolysis of oleuropein, and their numbers grow through (i) stage of maturity, (ii) processing line [6], and (iii) metabolism of oleuropein upon intake of oleuropein-based foods [17]. Hydroxytyrosol generally offers dietary health benefits in terms of antioxidation, anti-atherosclerosis, anti-carcinogenic and anti-inflammation [52]. The antioxidation potency of hydroxytyrosol is attributable to its ability to inhibit free radicals, mainly through donating hydrogen atoms, typically from hydroxyl groups, that initiates the formation of low-energy linkage with minimum reactivity arising from delocalisation in phenoxyl radical [6]. The hydroxytyrosol content of olive leaves, using high-performance liquid chromatography (HPLC) method, has been reported to be around $2.28 \mathrm{mg}$ per $100 \mathrm{~g}$ leaf extract [53].

Tyrosol, a group of phenolic alcohol, is usually present in a trace amount in olive leaves [51]. Due to its chemical stability, it is less prone to be degraded by auto-oxidation [54]. Although the antioxidative potency of tyrosol is relatively low (compared to those of other prominent phenolics such as flavonoids), it remains stable/unaffected during the process of oxidation [54]. The concentration of tyrosol in olive leaves, by maceration using ethanol and water solvent extraction, is approximately $0.0007 \mathrm{mg} / \mathrm{g}$ leaves, dry basis [50].

Table 1. Typical factors affecting concentration and functional properties of olive leaf phenolic compounds.

\begin{tabular}{ccc}
\hline Harvest Stage & Determinant & Reference \\
\hline \multirow{4}{*}{ Pre-harvest } & Geographical origin & {$[55]$} \\
\cline { 2 - 3 } & Maturity stage & {$[19]$} \\
\cline { 2 - 3 } & Climate & {$[56]$} \\
\cline { 2 - 3 } & Cultivar & {$[55,57]$} \\
\cline { 2 - 3 } & Tree/leaf lifetime & {$[57]$} \\
\hline \multirow{3}{*}{ Post-harvest } & Storage (time/temperature) & {$[19]$} \\
\cline { 2 - 3 } & Harvest time/period & {$[58]$} \\
\cline { 2 - 3 } & Extraction technique & {$[19,55]$} \\
\hline
\end{tabular}

\subsection{Triterpenoids}

Triterpenoids, namely triterpenes [59], are the secondary metabolites abundantly found in the waxes/outer coating of leaves $[60,61]$. They are chemically characterised by having six isoprene groups, typically made up of thirty carbons [62]. The occurrence of triterpenoids stems from the production of their precursor, squalene, through the ring formation of their lipidic molecules, farnesyl pyrophosphates [62]. Triterpenoids are chemically structured either in a free or glycosidic form (attached to carbohydrate molecules) [62]. They appreciably exert a defence against oxidative stress [63], carcinogenic, microbial, fungal, viral [64], atherogenic, gastrointestinal [64], and hypertensive disorders [65].

Olive leaves contain a considerable amount of pentacyclic triterpenoids, with oleanolic acid being the prevailing component ranging from 3.0 to $3.5 \%$ [66] up to $3.98 \%$ dry basis [64], and uvaol in the range of 0.07 to $0.14 \%$ [67]. Concentrations may vary depending on harvesting/sampling time and cultivar type [19]. Martín-García et al. [64], observed a high concentration of total triterpenoids in olive leaves of Picual cultivars, sampled in June, which constituted around $52.02 \mathrm{mg} / \mathrm{g}$ leaves, dry basis. Triterpene-rich olive leaves, with the presence of oleanolic acid and uvaol, have been found to exhibit suppression against diabetes and inflammatory diseases [68]. Other research, by Tsoumani et al. [69], confirmed that olive leave extracts, following hexane extraction that yielded oleanolic acid (around $56.6 \mathrm{mg} / \mathrm{g}$ ) and uvaol (around $37.8 \mathrm{mg} / \mathrm{kg}$ ), can display protection against platelet aggregation. 


\subsection{Tocopherols}

Tocopherols, the naturally occurring antioxidants, are grouped in fat soluble compounds, typically with vitamin E characteristics [70]. They are indicatively intrinsic to plants and other living organisms with photosynthetic activity [70,71]. The presence of tocopherols in most lipid-based foods such as seeds and vegetable oils is a paramount, mainly because of the protective action exerted by tocopherols to inhibit activities of reactive oxygen species such as peroxides [71] which in turn assists in the prevention of lipid peroxidation in the food [72]. The competitive reaction of tocopherol with peroxy free radicals brings about a limitation of free radical reaction with fatty acids of foods, and hence reducing the process of lipids autocatalysis/autoxidation [73]. The functionality of tocopherols has a great reliance on (i) occurrence and structural isomers (namely, alpha, beta, gamma, and delta), and (ii) their proportions and availability [73]. Research on optimisation of tocopherol recovery, through supercritical $\mathrm{CO}_{2}$ extraction technique, demonstrated that total tocopherol content accounts for $6.94 \mathrm{mg} / 100 \mathrm{~g}$ and $10.10 \mathrm{mg} / 100 \mathrm{~g}$ leaves, using $1 \mathrm{~h}$ and $2 \mathrm{~h}$ extraction time, respectively [74]. Concentration of alpha-tocopherols in olive leaves, is reportedly around $284.6 \mu \mathrm{g} / \mathrm{g}$ (dry basis) [75], $82.37 \mu \mathrm{g} / \mathrm{g}$ (dry basis) of Neb Jmel cultivar, and $10.12 \mu \mathrm{g} / \mathrm{g}$ (dry basis) of Oueslati cultivar [76].

\subsection{Pigments}

Pigments of plants are mainly responsible for the colour, light reactions (photosynthesis), ripening, and maturity of the plant components [77]. Chlorophylls and carotenoids, the pigments prevalent in plants, are valued for their colour attributes, and functional properties [78]. Carotenoids, the hydrophobic (fat-soluble) compounds, signify yellow/reddish orange colour of the cell membranes $[79,80]$. In addition to photosynthesising functions, the physiological activities of carotenoids are highlighted by their antioxidative effects, acting as free radical scavengers $[79,81]$, and carcinopreventive agents [79]. In the research of Tarchoune et al. [76], carotenoid concentration in olive leaves ranged from 26.90 to $44.33 \mu \mathrm{g} / \mathrm{g}$ (dry basis) in Neb Jmel and Oueslati cultivars, respectively. Olive leaves, rich in carotenoids and chlorophyll, have great potential for food functionalisation and may provide a sizable market opportunity in food sectors. These include the incorporation of pigment-rich olive leaves in olive oil which are reportedly effective in promoting the nutritional quality of the oil [76].

Chlorophylls, the fat-soluble [82] green pigments, appreciably contribute to photosynthesis in plants [83] through enabling the absorbance and transformation of light to chemical energy, and development of adenosine triphosphate [84]. They find applications in the food industry as food additives/colourants [85]. Chlorophyll-content foods confer a range of health protections that include disabling inflammation [85], oxidation and mutagenicity [86]. There are broadly two forms of chlorophyll pigments ( $a$ and $b$ ) that are distinguished by their chemical structure [87] and biological functions. Chlorophyll $a$ is the chief pigment in photosynthesising system, while chlorophyll $b$ is the secondary (accessory) component that facilitates greater light absorption and energy conversion [88]. The presence and proportion of chlorophyll notably determines the colour attributes of olive leaves [89]. The concentration of chlorophyll in Tunisian olive leaves (Oueslati cultivars) has been reported to be around $829.29 \mu \mathrm{g} / \mathrm{g}$ dry basis [76]. The proportion of the total chlorophyll in leaves may vary largely in various cultivars [89]. Moreover, the retention of chlorophyll and carotenoids potentially increases with the increase in the leaves' lifetime [90].

\section{Technological Aspects for Extraction of Bioactive Compounds from Olive Leaves}

The extraction process, that is the separation of desired (endogenous) ingredients, requires careful selection of methodologies. This is partly because unlike synthetic antioxidants, a great challenge is involved for the recovery of natural ingredients [91]. Although synthetic antioxidants confer efficiency and stability, by reason of being potentially hazardous, e.g., developing carcinogenicity and toxicity, the use of natural antioxidants is viewed as a safer and more appealing alternative [92]. The extraction 
system should be ideally designed to effectively satisfy processing, economics, and environmental sustainability. The main features associated with the sustainable extraction of functional ingredients from olive leaves are highlighted in Figure 1.

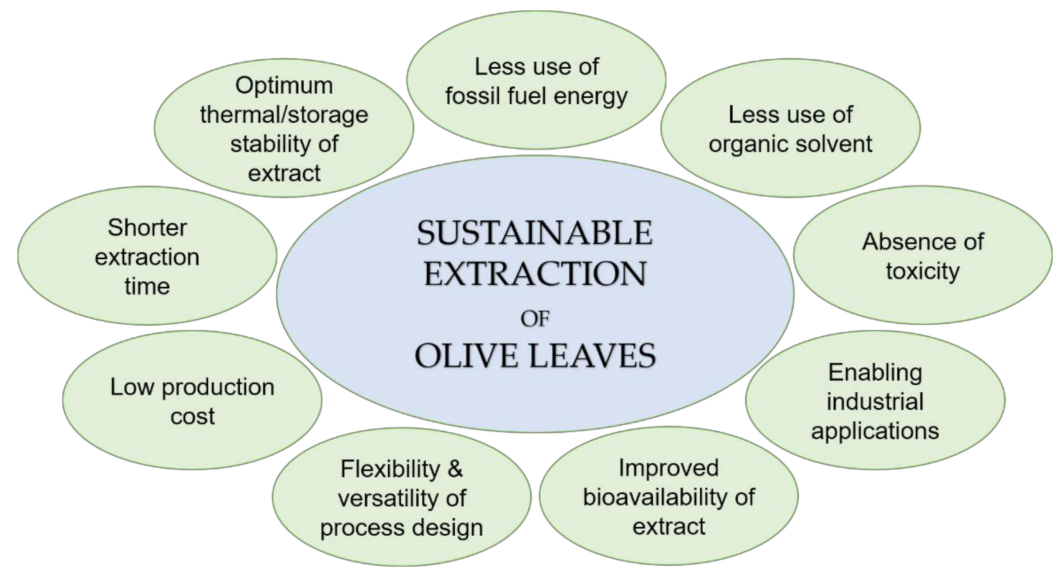

Figure 1. Factors involved in the sustainable extraction of active compounds from olive leaves.

The processing parameters, including sample preparation/handling, extraction time/temperature, and solvent type/ratio, are highly influential in the level of extractability and remaining functionality of the final product [93]. The choice of methodology depends on the intended final application/product that should be formulated suitably to be applicable to the desired extract composition and purity. For instance, the processing design may effectively enable the exertion of de-glycosylation and/or hydrolysis of oleuropein to hydroxytyrosol, that is appreciably prized for its biological activity and functionality [6]. However, if oleuropein is the desired final product, the extraction system should be optimally devised to ensure recovery of target pure/intact molecules with minimum degradation/chemical reaction. In this regard, the accuracy of the processing system control ("from farm to final product") is of great importance given the high susceptibility of the compounds to be extracted, particularly when aiming at more demanding applications, including pharmaceutical and medicinal.

\subsection{Stabilisation of Raw Biomass to Promote Physicochemical Quality of Olive Leaves}

Due to the high sensitivity of the bioactive compounds of olive leaves to environmental stresses, post-harvest treatments for biomass stabilisation may be crucial to allow maximum recovery of bioactivity. The trend of research studies on extraction systems has moved partly towards optimisation and efficiency of processing components and operational parameters associated with extraction system. These include drying treatments such as freeze drying and air drying [94]. Drying operation plays a major part in the resultant quantity and quality of the desired extract [93]. The research on optimisation of drying performance has progressed to some extent. Drying approaches such as $(i)$ tray drying based on Response Surface Methodology [95], (ii) heat pump drying [96], (iii) solar drying [97], and (iv) freeze drying [98] have shown to be highly effective in exerting the liberation of endogenous active compounds from olive leaves.

Selection of a suitable drying approach is important due to the presence of high moisture content in plant leaves that is a key factor in developing perishability and susceptibility to spoilage [99]. It is preferable to increase shelf-life by optimal drying operation to render the moisture unavailable for microbial/enzymatic activity and oxidation reaction [99]. Efficient drying, in part, exhibits optimal separation and purification of bioactive compounds, and thus the potential of maximising exploitation of olive leaves [96]. Drying operation parameters primarily include drying temperature and time, and their effect on drying performance [99]. High temperature with prolonged drying operation may destroy or alter the structure of bioactive ingredients. Considerable degradation of oleuropein 
during elevated drying temperature at $60^{\circ} \mathrm{C}$ has been reported by Malik and Bradford [100]. However, Ahmad-Qasem et al. [101], supported the applicability of hot air drying to olive leaves $\left(120^{\circ} \mathrm{C}\right.$ for $12 \mathrm{~min}$ ). The authors of this study found significant concentrations of phenolic compounds, particularly oleuropein $(p<0.05)$ in the extract. Another important factor is the selection of a suitable air circulation system to ensure that a consistent air flow enables optimal moisture removal from samples [99].

\subsection{Conventional Extraction Techniques}

Classical extraction techniques, commonly employed for the recovery of active compounds from olive leaves, involve a large proportion of organic solvents, using agitation and/or high temperature to maximise diffusivity/mass transfer of the desired compounds from food matrix [6]. Examples are percolation [6], solid-liquid extraction (e.g., maceration, Soxhlet extraction) [102], distillation, and heat reflux [103]. The choice of solvent is crucial to optimise the solubility and diffusivity of target ingredient/s [103]. Ethanol, methanol, and hydroalcoholic solvents are the most typical solvents used for extraction of a wide range of hydrophilic and lipophilic compounds in olive leaves. The conventional solid-liquid extraction methods, although offering some advantages (including effectiveness of maceration methods for heat-susceptible compounds, and the accuracy/reproducibility of Soxhlet methods), represent the downsides of (i) inefficient diffusivity and a slow/prolonged extraction process [103,104], (ii) using a prodigious amount of organic solvents (with potential toxicity), (iii) lengthy extraction time, and (iv) poor processing adaptability [6]. Other disadvantages inherent in both thermal and non-thermal conventional extractions are the high energy use, high production cost, and the potential incidence of degradation, arising from (i) prolonged subjection to solvents, e.g., in maceration [104], and (ii) the use of a high temperature involved in thermal operation [6,103].

\subsection{Alternative Strategies to Improve Extraction Performance}

Many attempts have been made to develop modified/advanced technologies for the efficient extraction of bioactive compounds from olive leaves [6,104]. In the literature, a range of emerging techniques have been proposed to date as alternative tools to replace traditional/inefficient processing systems. A summary of the typical methods investigated for the extraction of olive leaves is provided in Table 2.

The research of Lama-Muñoz et al. [104] (Table 2), on pressurised liquid extraction (PLE), using olive leaves with $5 \%$ moisture content and $80 \%$ ethanol at $190{ }^{\circ} \mathrm{C}$ during a 5 min extraction time, demonstrated that this method optimally increased the release of oleuropein $(63.35 \mathrm{~g} / \mathrm{kg}$ leaves $)$ and luteolin-7-O-glucoside ( $2.71 \mathrm{~g} / \mathrm{kg}$ leaves). Pressurised liquid extraction relatively helps address the hurdle of slow processing inherent in traditional methods, although it entails large capital investment but it offers advantages of low running/input cost [104].

The steam explosion method has been studied by Romero-García et al. [102] to optimise the extraction of sugars and antioxidant compounds from olive tree leaves. Although sugars were the main compounds recovered ( $70 \%$ from the initial content), the authors reported significant extraction of oleuropein, hydroxytyrosol and flavonoids, that, respectively, represented $1613 \mathrm{mg}, 260 \mathrm{mg}$, and $123 \mathrm{mg}$ per $100 \mathrm{~g}$ dry leaves, with the extraction temperature of $180^{\circ} \mathrm{C}$ for $4 \mathrm{~min}$.

Recovery of olive mill leaves, using ultrasound assisted extraction (UAE) method, with ethanol solvent within a $30 \mathrm{~min}$ extraction time, improved the concentration $(30 \%)$ of oleuropein in extracted leaves [7]. The principal limitations of UAE include non-selective extraction [105], variability of ultrasound energy, and possible alteration of molecular structure of active components [106].

Da Rosa et al. [107], assessed extraction of total phenolic compounds from olive leaves using three methods (Table 2). By comparing the efficacy of the extraction methods examined in their research, microwave assisted extraction (MAE) was found to be the most efficient approach (using $86^{\circ} \mathrm{C}$ for $3 \mathrm{~min}$ ). Their study demonstrated that MAE, where water was used as solvent, provides efficacy over the conventional (maceration) method. An increase of $82 \%$ recovery of total phenolics was observed. These authors suggested the potential efficacy of microwave assisted extraction when 
incorporated in pre-treatment step during ultrasonic assisted extraction. Sánchez-Ávila et al. [108] also worked on optimisation design of MAE for the quantification of triterpene derivatives in olive leaves and confirmed the efficacy of this method in the extraction yield. The optimum conditions of independent variables determined in their study included: (i) irradiation time (5 min), (ii) irradiation power $(180 \mathrm{~W})$, and the special focus on (iii) solvent ratio, optimally ethanol/water (80:20). Application of MAE is beneficial in terms of (i) short extraction time, ii) extraction efficiency [107,109], (iii) appealing physicochemical quality, and (iv) no waste of heat energy to environment [109]. However, the extraction yield is constrained by the type of solvents, entailing dielectric (dipole) solvents capable of absorbing microwave energy [109]. Further, the scale-up of MAE systems may represent major drawbacks, as the length of penetration of microwaves is rather limited.

Table 2. Summary of existing techniques proposed for olive leave extraction.

\begin{tabular}{|c|c|c|c|}
\hline Nature of Study & Extraction Method & Advantage & Reference \\
\hline $\begin{array}{l}\text { Optimising extraction of } \\
\text { total phenolic compounds } \\
\text { (including oleuropein, } \\
\text { flavonoids, } \\
\text { luteoline-7-O-glucoside) }\end{array}$ & $\begin{array}{l}\text { Pressurised liquid-extraction } \\
\text { (optimised by Response } \\
\text { Surface Methodology) } \\
\text { Solvent: ethanol/water }\end{array}$ & $\begin{array}{l}\text { Efficient method for } \\
\text { isolation of phytochemicals; } \\
\text { low operation/input cost; } \\
\text { high speed; greater recovery }\end{array}$ & [104] \\
\hline $\begin{array}{l}\text { Study of various extraction } \\
\text { methods and assess the } \\
\text { influence of designed } \\
\text { parameters on recovery of } \\
\text { total phenolics and } \\
\text { antioxidant activity }\end{array}$ & $\begin{array}{c}\text { Microwave-assisted } \\
\text { extraction (MAE) } \\
\text { Ultrasonic assisted } \\
\text { extraction (UAE) } \\
\text { Conventional (maceration) }\end{array}$ & $\begin{array}{l}\text { MAE: Most efficient method; } \\
\text { less time consuming } \\
\text { UAE: Lower temperature } \\
\text { provides better quality and } \\
\text { greater yield }\end{array}$ & [107] \\
\hline $\begin{array}{l}\text { Determination of increasing } \\
\text { oleuropein isolation }\end{array}$ & $\begin{array}{l}\text { Hybrid extraction technique: } \\
\text { aqueous ethanolic extract } \\
\text { (from liquid-solid extraction) } \\
\text { was subjected to } \\
\text { supercritical antisolvent } \\
\text { extraction, to obtain } \\
\text { precipitated/concentrated } \\
\text { oleuropein }\end{array}$ & $\begin{array}{l}\text { Enables precipitation and } \\
\text { formation of oleuropein } \\
\text { powder; efficient method. } \\
\text { Only traces of ethanol } \\
\text { remain in final extract }\end{array}$ & [110] \\
\hline $\begin{array}{l}\text { Investigation of total } \\
\text { phenolic compounds } \\
\text { through developing } \\
\text { supercritical fluid extraction }\end{array}$ & Supercritical fluid extraction & $\begin{array}{l}\text { High-speed; automated } \\
\text { means; requires less solvent; } \\
\text { selective isolation }\end{array}$ & [111] \\
\hline $\begin{array}{l}\text { Effective development of } \\
\text { phenolic extraction using } \\
\text { high voltage electrical } \\
\text { discharges compared to } \\
\text { conventional method }\end{array}$ & $\begin{array}{l}\text { High voltage electric } \\
\text { discharges (characterisation } \\
\text { analysis performed by } \\
\text { ultra-performance liquid } \\
\text { chromatography-tandem } \\
\text { mass spectrometry) }\end{array}$ & $\begin{array}{l}\text { Use of organic solvents; } \\
\text { effective extraction method } \\
\text { (high extractability) }\end{array}$ & [103] \\
\hline
\end{tabular}

As indicated in Table 2, in another study by Baldino et al. [110], using an integration of liquid-liquid extraction (to extract olive leaves using ethanol), and supercritical antisolvent extraction (to recover oleuropein from aqueous ethanolic extract), demonstrated around $36 \%$ isolated (powder) oleuropein, with an extraction pressure of 150 bar at $35^{\circ} \mathrm{C}$. Le Floch et al. [111] employed supercritical fluid extraction (SFE), using $10 \%$ methanol of $\mathrm{CO}_{2}$ with the extraction pressure of 334 at $100{ }^{\circ} \mathrm{C}$ for $140 \mathrm{~min}$ (Table 2). In their research, total phenolic compounds (TPC), using Folin-Ciocalteu reagent assay, was assessed, and compared to the sonication-assisted liquid solvent extraction. The concentration of TPC obtained by SFE was higher than other solvents used in sonication, including $n$-hexane, but the percentage yield of TPC was lower than that extracted with methanol which represented a $45 \%$ yield. Supercritical extraction using $\mathrm{CO}_{2}$ has shown efficacy in isolation of plant bioactive constituents [110]. 
The main advantages include (i) using lower temperatures [112], (ii) allowing extraction selectivity, and (iii) enabling rapid extraction [113]. However, due to relative polarity of phenolics, the process needs the inclusion of polar solvent, namely, a modifier to help increase the solubility (in $\mathrm{CO}_{2}$ ), and extraction yield [112].

Electric field-assisted extraction is also regarded as an emerging aid which encompasses both thermal and non-thermal extraction systems and has great potential for the extraction of active compounds from olive tree leaves. Moderate electric fields and the associated ohmic heating (where heat is generated due to the application of an electric field to a semi-conductive sample) may be used which allows (i) internal, uniform and fast heating, enabling favourable decrease in processing time with minimum thermal degradation of compounds), (ii) partial cell wall permeabilization, and (iii) minimum energy and time consumptions [114]. On the other hand, pulsed electric fields uses high voltage electric fields applied in extremely short pulses (to avoid heating) to destroy the cell membrane structure, improving the release of the bio-compounds to be extracted [114]. In this context, the experiment of Žuntar et al. [103], demonstrates that a non-thermal high voltage electrical discharges (Table 2) is a viable technique for phenolic extraction from olive leaves. It enables greater rate of diffusivity by exerting the cell rupture and forcing the diffusion of mass transfer from internal part of cells to the external surrounding/solution, and thus assisting in the increment of yield within less time. However, other important factors inherent in the potential development of chemical residue and corrosivity of system components (e.g., when using less expensive electrodes) are yet to be identified. In addition, the upscaling operation system entails large investment, mainly for apparatus and processing inputs [103].

\section{Significance of Stability of Olive Leaf Extract}

It is important to take the factor of preservation and delivery of the final extracts into consideration. This is mainly because many bioactive compounds, including phenolics, are inherently susceptible to heat, light and oxygen, together with (i) variability in water solubility, (ii) high metabolic rate, and (iii) tendency of being expelled instantaneously from the body. This may substantially reduce biological availability and functionality of polyphenols [115]. In addition, non-phenolic compounds such as triterpenoids are likely to be less bioavailable, due to their poor solubility/hydrophilicity which in turn hinders their biological functions [116]. Therefore, and besides the necessary caution during harvest and processing mentioned in the previous section, post-processing olive leaves by-products stabilization is also of utmost importance. The most common approaches described for this purpose involve different types of encapsulation techniques, allowing the protection of the extracts against various environmental stresses as well as controlled release of the bioactivity, at the desired time and place.

Application of various techniques based on nanotechnology, such as nano-structuring and polymeric nanoparticles, helps improve solubility, and functionality of these compounds [116]. Encapsulation of olive leaf extract, e.g., by freeze drying, using cyclodextrin for encapsulation [117], or by water in oil (W/O) nano-emulsion using soybean oil, has been considered a markedly useful technique in this regard [118]. In a research, carried out by Urzúa et al. [119], through examining microencapsulation ability in preservation of phenolics and their bioactive potency, olive leaf extracts were encapsulated with inulin by means of spray drying. The outcome of their study showed that microencapsulation was highly efficient in preserving active compounds (oleuropein yielded above $87 \%$ in the encapsulated leaf extract). Additioanlly, Soleimanifar et al. [120], in their research on nanoencapsulation of olive leaf phenolics by whey protein electro-spraying (using low temperature without solvent), postulated the use of this technique as a propitious approach for protecting functional constituents of olive leaves. 


\section{Potential Industrial Applications of Olive Leaf Extracts}

Olive leaves, together with having great potential for medicinal, cosmetic [19], and pharmaceutical uses, could find applications in functionalising/developing a wide range of food products [17]. The addition of olive leaf extract to vegetable oils is believed to be effective in promoting oxidation stability and retaining nutritive components of oils, leading to a longer shelf-life [121]. Ammar et al. [122], conducted research on the effect of addition of olive leaves in extra virgin olive oil (added prior to oil extraction) on phenolic profile of the extracted oil samples from Tunisian cultivars. These authors found a significant increment of phenolic content in the recovered oil, from Chétoui cultivar, treated with $3 \%$ of olive leaves. Incorporation of olive leaves (3\%) to Tunisian olive oils (Oueslati cultivar) has shown to increase the concentration of polyphenols (44\%), chlorophyll (around 67\%), and carotenoids (around 62\%) in the oil [76]. Sevim et al. [123] also described that inclusion of olive leaves in olive oil has potential to promote the bioactive profile of the oil stored for 18 months. Significant increment of alpha-tocopherols, phenolics, and chlorophyll proportions as well as antioxidant activity were observed in the leave-treated oils $p<0.001$.

The significance of developing oxidative stability of cooking oils, particularly when using deep frying or a high temperature, is primarily due to oxidative susceptibility of vegetable oils during cooking process rendering unappealing changes in the food structure with potential degradation of nutritional/sensory quality [124]. Addition of olive leaf extracts to sunflower, palm, and olive oil (TPC concentrations of extracts: 120 and $240 \mathrm{mg} / \mathrm{Kg}$ oil) was examined by Chiou et al. [125] for antioxidation properties in the fried potato chips (French fries). It was found that polyphenolic concentration significantly increased as much as three to 60-fold greater than corresponding compounds in potato chips fried with commercial oils samples. Their study also indicated that oleuropein represented the prevailing phenolic constituent in the leaf extract (1.25 g/Kg leaves). Effectiveness of upgrading stabilisation of refined olive oil to the extent of virgin olive oil is potentially achievable when olive leaves $(1 \mathrm{Kg})$ is incorporated in 50 to $230 \mathrm{~L}$ refined oil. However, this amount has a huge reliance on variations in cultivars, sampling/harvesting time, and chemical features of the extracted oil [126].

Inclusion of phenolic-rich olive leaf extract in the food system, as an alternative functional source, compared to the expensive purified biomolecules such as oleuropein, offers the advantage of being a low-cost processing means as it eliminates the need for the purification step, while being considerably effective. In this regard, Zoidou et al. [44] investigated the effectiveness of incorporation of oleuropein-rich olive leaf extract in yogurt, through adding leaf extract to the milk ingredient ( $0.43 \mathrm{mg}$ extract per $\mathrm{mL}$ milk) during processing of yogurt production. These authors postulated the great potential of olive leave extract (rich in oleuropein), as an inexpensive functional material, in the enrichment of yogurt products.

\section{Future Trends}

Maximizing extraction efficacy (considering both yield and functionality) while minimizing overall cost is evidently a desired approach. Many studies on the analysis and exploitation of olive leaves have been published to date but further details on the exploration of viable approaches based on environmental and economic sustainability are needed to fill the knowledge gap currently exists. Among the challenges involved in the isolation of phytochemicals from olive leaves are the following: (i) variability in quantification and characterisation, (ii) achieving reproducibility and flexibility of extraction approach, (iii) enabling simplicity and adaptability to various industrial applications, including functional foods and nutraceutical supplements $(i v)$ substantiating stability and potency of phenolic extracts, and (v) ensuring up-scalability.

Another challenge, when using a new technique, is the factor of chemical residue that brings about toxic hazards to the environment. There is a growing trend towards researching in this area, via minimising toxic processing inputs, to present a competitively innovative/non-conventional alternative, or to optimally complement the traditional methods. Furthermore, current in vivo studies related to the toxicological measures of olive leaves appear to be limited, and thus, this requires further 
research to conclusively determine this, even though olive leaves have been generally considered natural/safe products. From the perspective of oleuropein, the median lethal dose in rodents is reportedly greater than $3000 \mathrm{mg} / \mathrm{Kg}$ (following oral administration), and greater than $1000 \mathrm{mg} / \mathrm{Kg}$ (following intraperitoneal injection) [44].

Additionally, analytical challenges (that are partly attributed to the variability in phenolic biosynthesis and bioactivity among various cultivars) need to be taken into consideration. The innovative analytical methods such as metabolic fingerprinting, as a useful means, effectively helps classify cultivars based on their molecular profile that can be used as chemical markers. Di Donna et al. [58], in their study to determine whether the selected cultivars are distinguished/classified within different growing sites, performed a supervised pattern analysis, including soft independent modelling of class analogy that was found to be effective in the predictive analysis of cultivars and growing sites. Furthermore, it is essential to understand the efficacy of adequate proportions of active components in olive leaf extracts to optimally enable the exertion of their functionality in food/non-food product developments.

Olive leaves, although endowed with bioactivity which are of benefit to developing added-value products, the inherently low recovery yields, and complexity of active compounds, may hamper expensive/demanding downstream processing. On the other hand, current studies point to applying integrated approaches that ensure maximum re-use of the available biomass, preferably towards the whole use of different olive-based residue fractions. The United Nations' 2030 Agenda for Sustainable Development has emphasised specific goals on sustainability and responsible production side-by-side with economic growth and industrial innovation. In this context, application of a diverse range of biomass/by-products, generated in agricultural and industrial processing of olives, helps contribute to economic and environmental sustainability. Future perspectives seemingly incorporate deeper analysis of (i) flexible on-site or near-site processing of plants, (ii) biomass stabilisation, (iii) transportation needs, (iv) exploitation of various types of residues/by-products of plants, and (v) sequential extraction of various recoverable fractions.

\section{Conclusions}

A large proportion of olive leaves, the by-products of the agricultural and processing methods of olive crops, does not end up being utilised and their disposal represents huge economic and environmental impacts. These residues are abundant in valuable bio-compounds and their inclusion in the food/dietary system is decidedly a preferable alternative to using synthetic counterparts. They have great market potential for industrial applications as functional/natural ingredients and high-added value products. However, there are principal factors involved in the level of extractability and biological potency of phytonutrients. Among the major determinants, the type of extraction system has been emphasised in many studies. The selection of a viable and inexpensive processing approach to accommodate an optimum liberation of desired molecules, with especial attention to environmental sustainability, is challenging work. In the literature, numerous advanced methodologies have been examined to develop sustainable processing techniques to replace the conventional/expensive extraction systems currently used. Many research studies have postulated efficient processing designs to increase recovery of biomolecules and decrease: (i) toxic extraction solvents, (ii) fossil fuel energy, (iii) manufacturing cost, and (iv) processing time. These findings are potentially propitious but, having said that, olive leaves have currently found limited commercial use and the industrial applications are still unable to adapt the new/proposed techniques, in part because of the operation/system complexity and overall production expenses. This may hamper broader scientific efforts to provide a feasible means, with minimum challenges, for valorisation of olive leaves which enables (i) minimum operation costs, (ii) simple and flexible processing protocol, and (iii) accessible system components. Performance of a sustainable bio-processing strategy helps reach the goal of zero disposal/green processing of olive leaf by-products while assuring an acceptable quality of functional/natural products to satisfy both consumers and industrial needs. 
Author Contributions: Conceptualization: F.S.M., J.A.T. and C.M.R.R.; Literature Reviewing: F.S.M., J.A.T. and C.M.R.R.; Writing-Original Draft: F.S.M., J.A.T. and C.M.R.R.; Writing-Review and Editing: F.S.M., J.A.T. and C.M.R.R. All authors have read and agreed to the published version of the manuscript.

Funding: This work was supported by the Portuguese Foundation for Science and Technology (FCT), under the scope of the strategic funding of UID/BIO/04469/2020 unit.

Conflicts of Interest: The authors declare no conflict of interest.

\section{References}

1. Gilani, A.H.; Khan, A.U. Medicinal Value of Combination of Cholinergic and Calcium Antagonist Constituents in Olives. In Olives and Olive Oil in Health and Disease Prevention; Preedy, V.R., Watson, R.R., Eds.; Elsevier: Amsterdam, The Netherlands, 2010; pp. 835-843.

2. Mannina, L.; Segre, A.L. NMR and olive oils: A geographical characterization. In Olives and Olive Oil in Health and Disease Prevention; Preedy, V.R., Watson, R.R., Eds.; Elsevier: Amsterdam, The Netherlands, 2010; pp. 117-124.

3. Ray, N.B.; Lam, N.T.; Luc, R.; Bonvino, N.P.; Karagiannis, T.C. Cellular and molecular effects of bioactive phenolic compounds in olives and olive oil. In Olive and Olive Oil Bioactive Constituents; Boskou, D., Ed.; AOCS Press, Elsevier: Amsterdam, The Netherlands, 2015; pp. 53-91.

4. Caballero, B.; Trugo, L.C.; Finglas, P.M. Encyclopedia of Food Sciences and Nutrition, 2nd ed.; Academic Press, Elsevier: Amsterdam, The Netherlands, 2003.

5. Zipori, I.; Erel, R.; Yermiyahu, U.; Ben-Gal, A.; Dag, A. Sustainable Management of Olive Orchard Nutrition: A Review. Agriculture 2020, 10, 1-21. [CrossRef]

6. Rahmanian, N.; Jafari, S.M.; Wani, T.A. Bioactive profile, dehydration, extraction and application of the bioactive components of olive leaves. Trends Food Sci. Technol. 2015, 42, 150-172. [CrossRef]

7. Del Mar Contreras, M.; Lama-Muñoz, A.; Espínola, F.; Moya, M.; Romero, I.; Castro, E. Valorization of olive mill leaves through ultrasound-assisted extraction. Food Chem. 2020, 314, 1-8.

8. Abaza, L.; Taamalli, A.; Nsir, H.; Zarrouk, M. Olive tree (Olea europeae L.) leaves: Importance and advances in the analysis of phenolic compounds. Antioxidants 2015, 4, 682-698. [CrossRef] [PubMed]

9. Lama-Muñoz, A.; del Mar Contreras, M.; Espínola, F.; Moya, M.; Romero, I.; Castro, E. Content of phenolic compounds and mannitol in olive leaves extracts from six Spanish cultivars: Extraction with the Soxhlet method and pressurized liquids. Food Chem. 2020, 320, 1-9. [CrossRef] [PubMed]

10. Romero-García, J.M.; Niño, L.; Martínez-Patiño, C.; Álvarez, C.; Castro, E.; Negro, M.J. Biorefinery based on olive biomass. State of the art and future trends. Bioresour. Technol. 2014, 159, 421-432. [CrossRef] [PubMed]

11. Talhaoui, N.; Taamalli, A.; Gómez-Caravaca, A.M.; Fernández-Gutiérrez, A.; Segura-Carretero, A. Phenolic compounds in olive leaves: Analytical determination, biotic and abiotic influence, and health benefits. Food Res. Int. 2015, 77, 92-108. [CrossRef]

12. Bulotta, S.; Corradino, R.; Celano, M.; D'Agostino, M.; Maiuolo, J.; Oliverio, M.; Procopio, A.; Iannone, M.; Rotiroti, D.; Russo, D. Antiproliferative and antioxidant effects on breast cancer cells of oleuropein and its semisynthetic peracetylated derivatives. Food Chem. 2011, 127, 1609-1614. [CrossRef]

13. Cavaca, L.A.; López-Coca, I.M.; Silvero, G.; Afonso, C.A. The olive-tree leaves as a source of high-added value molecules: Oleuropein. In Studies in Natural Products Chemistry; Atta-Ur-Rahman, Ed.; Elsevier: Amsterdam, The Netherlands, 2020; Volume 64, pp. 131-180.

14. Benavente-García, O.; Castillo, J.; Lorente, J.; Ortuño, A.D.R.J.; Del Rio, J.A. Antioxidant activity of phenolics extracted from Olea europaea L. leaves. Food Chem. 2000, 68, 457-462. [CrossRef]

15. Jemai, H.; Fki, I.; Bouaziz, M.; Bouallagui, Z.; El Feki, A.; Isoda, H.; Sayadi, S. Lipid-lowering and antioxidant effects of hydroxytyrosol and its triacetylated derivative recovered from olive tree leaves in cholesterol-fed rats. J. Agric. Food Chem. 2008, 56, 2630-2636. [CrossRef]

16. Balasundram, N.; Sundram, K.; Samman, S. Phenolic compounds in plants and agri-industrial by-products: Antioxidant activity, occurrence, and potential uses. Food Chem. 2006, 99, 191-203. [CrossRef]

17. Erbay, Z.; Icier, F. The importance and potential uses of olive leaves. Food Rev. Int. 2010, 26, 319-334. [CrossRef]

18. Acar-Tek, N.; Ağagündüz, D. Olive Leaf (Olea europaea L. folium): Potential Effects on Glycemia and Lipidemia. Ann. Nutr. Metab. 2020, 76, 63-68. [CrossRef] [PubMed] 
19. Tsimidou, M.Z.; Papoti, V.T. Bioactive ingredients in olive leaves. In Olives and Olive Oil in Health and Disease Prevention; Preedy, V.R., Watson, R.R., Eds.; Elsevier: Amsterdam, The Netherlands, 2010; pp. 349-356.

20. Souilem, S.; Fki, I.; Kobayashi, I.; Khalid, N.; Neves, M.A.; Isoda, H.; Sayadi, S.; Nakajima, M. Emerging technologies for recovery of value-added components from olive leaves and their applications in food/feed industries. Food Bioprocess Technol. 2017, 10, 229-248. [CrossRef]

21. Hamzalığlu, A.; Gökmen, V. Interaction between Bioactive Carbonyl Compounds and Asparagine and Impact on Acrylamide. In Acrylamide in Food: Analysis, Content and Potential Health Effects; Gökmen, V., Ed.; Elsevier: Amsterdam, The Netherlands, 2016; pp. 355-376.

22. Bernhoft, A. A. A brief review on bioactive compounds in plants. In Bioactive Compounds in Plants-Benefits and Risks for Man and Animals; The Norwegian Academy of Science and Letters: Oslo, Norway, 2010; Volume 50, pp. 11-17.

23. Ortega, A.M.M.; Campos, M.R.S. Bioactive Compounds as Therapeutic Alternatives. In Bioactive Compounds: Health Benefits and Potential Applications; Campos, M.R.S., Ed.; Woodhead Publishing: Cambridge, UK, 2019; pp. 247-264.

24. Šaponjac, V.T.; Čanadanović-Brunet, J.; Ćetković, G.; Djilas, S. Detection of bioactive compounds in plants and food products. In Emerging and Traditional Technologies for Safe, Healthy and Quality Food; Nedović, V., Peter Raspor, P., Jovanka Lević, J., Šaponjac, V.T., Barbosa-Cánovas, G.V., Eds.; Springer: Cham, Switzerland, 2016; pp. 81-109.

25. Galanakis, C.M. Introduction. In Nutraceutical and Functional Food Components: Effects of Innovative Processing Techniques; Elsevier: Oxford, UK, 2017; pp. 1-10.

26. Moreno, J.; Peinado, R. Polyphenols. In Enological Chemistry; Elsevier, Academic Press: Cambridge, MA, USA, 2012; pp. 53-76.

27. Souto, E.B.; Sampaio, A.C.; Campos, J.R.; Martins-Gomes, C.; Aires, A.; Silva, A.M. Polyphenols for skin cancer: Chemical properties, structure-related mechanisms of action and new delivery systems. In Studies in Natural Products Chemistry; Rahman, A., Ed.; Elsevier: Amsterdam, The Netherlands, 2019; Volume 63, pp. 21-42.

28. Petti, S.; Scully, C. Polyphenols, oral health and disease: A review. J. Dent. 2009, 37, 413-423. [CrossRef]

29. Belitz, H.D.; Grosch, W.; Schieberle, P. Food Chemistry, 4th ed.; Springer: Berlin/Heidelberg, Germany, 2009.

30. Oniszczuk, A.; Widelska, G.; Wójtowicz, A.; Oniszczuk, T.; Wojtunik-Kulesza, K.; Dib, A.; Matwijczuk, A. Content of phenolic compounds and antioxidant activity of new gluten-free pasta with the addition of chestnut flour. Molecules 2019, 24, 1-14. [CrossRef]

31. Shahidi, F.; Ambigaipalan, P. Phenolics and polyphenolics in foods, beverages and spices: Antioxidant activity and health effects-A review. J. Funct. Foods 2015, 18, 820-897. [CrossRef]

32. Wojtunik-Kulesza, K.; Oniszczuk, A.; Oniszczuk, T.; Combrzyński, M.; Nowakowska, D.; Matwijczuk, A. Influence of In Vitro Digestion on Composition, Bioaccessibility and Antioxidant Activity of Food Polyphenols-A Non-Systematic Review. Nutrients 2020, 12, 1401. [CrossRef]

33. Oniszczuk, A.; Wójtowicz, A.; Oniszczuk, T.; Matwijczuk, A.; Dib, A.; Markut-Miotła, E. Opuntia Fruits as Food Enriching Ingredient, the First Step towards New Functional Food Products. Molecules 2020, 25, 916. [CrossRef]

34. Segura-Carretero, A.; Menéndez-Menéndez, J.; Fernández-Gutiérrez, A. Polyphenols in olive oil: The importance of phenolic compounds in the chemical composition of olive oil. In Olives and Olive Oil in Health and Disease Prevention; Preedy, V.R., Watson, R.R., Eds.; Elsevier Inc.: Amsterdam, The Netherlands, 2010; pp. 167-175.

35. Huang, Y.L.; Oppong, M.B.; Guo, Y.; Wang, L.Z.; Fang, S.M.; Deng, Y.R.; Gao, X.M. The Oleaceae family: A source of secoiridoids with multiple biological activities. Fitoterapia 2019, 136, 1-18. [CrossRef]

36. Mander, L.; Liu, H.W. Comprehensive Natural Products II: Chemistry and Biology; Townsend, C.A., Ebizuka, Y., Eds.; Elsevier: Amsterdam, The Netherlands, 2010; Volume 1.

37. Rodriguez, S.; Marston, A.; Wolfender, J.L.; Hostettmann, K. Iridoids and secoiridoids in the Gentianaceae. Curr. Org. Chem. 1998, 2, 627-648.

38. Nediani, C.; Ruzzolini, J.; Romani, A.; Calorini, L. Oleuropein, a Bioactive Compound from Olea europaea L., as a Potential Preventive and Therapeutic Agent in Non-Communicable Diseases. Antioxidants 2019, 8, 1-26. [CrossRef] [PubMed]

39. Romani, A.; Mulas, S.; Heimler, D. Polyphenols and secoiridoids in raw material (Olea europaea L. leaves) and commercial food supplements. Eur. Food Res. Technol. 2017, 243, 429-435. [CrossRef] 
40. Bouaziz, M.; Sayadi, S. Isolation and evaluation of antioxidants from leaves of a Tunisian cultivar olive tree. Eur. J. Lipid Sci. Technol. 2005, 107, 497-504. [CrossRef]

41. Visioli, F.; Bellosta, S.; Galli, C. Oleuropein, the bitter principle of olives, enhances nitric oxide production by mouse macrophages. Life Sci. 1998, 62, 541-546. [CrossRef]

42. Geyikoglu, F.; Isikgoz, H.; Onalan, H.; Colak, S.; Cerig, S.; Bakir, M.; Hosseinigouzdagani, M.; Koc, K.; Erol, H.S.; Saglam, Y.S.; et al. Impact of high-dose oleuropein on cisplatin-induced oxidative stress, genotoxicity and pathological changes in rat stomach and lung. J. Asian Nat. Prod. Res. 2017, 19, 1214-1231. [CrossRef]

43. Paiva-Martins, F.; Pinto, M. Isolation and characterization of a new hydroxytyrosol derivative from olive (Olea europaea) leaves. J. Agric. Food Chem. 2008, 56, 5582-5588. [CrossRef]

44. Zoidou, E.; Melliou, E.; Moatsou, G.; Magiatis, P. Preparation of Functional Yogurt Enriched with Olive-Derived Products. In Yogurt in Health and Disease Prevention; Shah, N.P., Ed.; Elsevier: Amsterdam, The Netherlands, 2017; pp. 203-220.

45. Xu, F.; Li, Y.; Zheng, M.; Xi, X.; Zhang, X.; Han, C. Structure properties, acquisition protocols, and biological activities of oleuropein aglycone. Front. Chem. 2018, 6, 1-10. [CrossRef]

46. Siliani, S.; Mattei, A.; Innocenti, L.B.; Zanoni, B. Bitter taste and phenolic compounds in extra virgin olive oil: An empirical relationship. J. Food Qual. 2006, 29, 431-441. [CrossRef]

47. Leri, M.; Natalello, A.; Bruzzone, E.; Stefani, M.; Bucciantini, M. Oleuropein aglycone and hydroxytyrosol interfere differently with toxic A $\beta 1-42$ aggregation. Food Chem. Toxicol. 2019, 129, 1-12. [CrossRef]

48. Babu, P.V.A.; Liu, D. Flavonoids and cardiovascular health. In Complementary and Alternative Therapies and the Aging Population; Watson, R.R., Ed.; Elsevier Inc.: Amsterdam, The Netherlands, 2009; pp. 371-392.

49. Havsteen, B.H. The biochemistry and medical significance of the flavonoids. Pharmacol. Ther. 2002, 96, 67-202. [CrossRef]

50. Ghomari, O.; Sounni, F.; Massaoudi, Y.; Ghanam, J.; Kaitouni, L.B.D.; Merzouki, M.; Benlemlih, M. Phenolic profile (HPLC-UV) of olive leaves according to extraction procedure and assessment of antibacterial activity. Biotechnol. Rep. 2019, 23, 1-7. [CrossRef] [PubMed]

51. Tamasi, G.; Bonechi, C.; Belyakova, A.; Pardini, A.; Rossi, C. The olive tree, a source of antioxidant compounds. J. Siena Acad. Sci. 2016, 8, 10-29. [CrossRef]

52. Martínez, L.; Ros, G.; Nieto, G. Hydroxytyrosol: Health benefits and use as functional ingredient in meat. Medicines 2018, 5, 1-12. [CrossRef]

53. Fki, I.; Sayadi, S.; Mahmoudi, A.; Daoued, I.; Marrekchi, R.; Ghorbel, H. Comparative Study on Beneficial Effects of Hydroxytyrosol-and Oleuropein-Rich Olive Leaf Extracts on High-Fat Diet-Induced Lipid Metabolism Disturbance and Liver Injury in Rats. Biomed Res. Int. 2020, 2020, 1-15. [CrossRef]

54. Karković Marković, A.; Torić, J.; Barbarić, M.; Jakobušić Brala, C. Hydroxytyrosol, tyrosol and derivatives and their potential effects on human health. Molecules 2019, 24, 1-39. [CrossRef]

55. Bilgin, M.; Şahin, S. Effects of geographical origin and extraction methods on total phenolic yield of olive tree (Olea europaea) leaves. J. Taiwan Inst. of Chem. Eng. 2013, 44, 8-12. [CrossRef]

56. Wang, B.; Qu, J.; Feng, S.; Chen, T.; Yuan, M.; Huang, Y.; Liao, J.; Yang, R.; Ding, C. Seasonal Variations in the Chemical Composition of Liangshan Olive Leaves and Their Antioxidant and Anticancer Activities. Foods 2019, 8, 1-17. [CrossRef]

57. Ranalli, A.; Contento, S.; Lucera, L.; Di Febo, M.; Marchegiani, D.; Di Fonzo, V. Factors affecting the contents of iridoid oleuropein in olive leaves (Olea europaea L.). J. Agric. Food Chem. 2006, 54, 434-440. [CrossRef]

58. Di Donna, L.; Mazzotti, F.; Naccarato, A.; Salerno, R.; Tagarelli, A.; Taverna, D.; Sindona, G. Secondary metabolites of Olea europaea leaves as markers for the discrimination of cultivars and cultivation zones by multivariate analysis. Food Chem. 2010, 121, 492-496. [CrossRef]

59. Howes, M.J.R. Phytochemicals as anti-inflammatory nutraceuticals and phytopharmaceuticals. In Immunity and Inflammation in Health and Disease: Emerging Roles of Nutraceuticals and Functional Foods in Immune Support; Chatterjee, S., Jungraithmayr, W., Bagchi, D., Eds.; Elsevier Inc.: Amsterdam, The Netherlands, 2018; pp. 363-388.

60. Jäger, S.; Trojan, H.; Kopp, T.; Laszczyk, M.N.; Scheffler, A. Pentacyclic triterpene distribution in various plants-rich sources for a new group of multi-potent plant extracts. Molecules 2009, 14, 2016-2031. [CrossRef] [PubMed]

61. Stiti, N.; Hartmann, M.A. Nonsterol triterpenoids as major constituents of Olea europaea. J. Lipids 2012, 2012, 1-13. [CrossRef] [PubMed] 
62. Du, J.R.; Long, F.Y.; Chen, C. Research progress on natural triterpenoid saponins in the chemoprevention and chemotherapy of cancer. In The Enzymes; Bathaie, Z.S., Tamanoi, F., Eds.; Elsevier: Amsterdam, The Netherlands, 2014; Volume 36, pp. 95-130.

63. Sánchez-Quesada, C.; López-Biedma, A.; Warleta, F.; Campos, M.; Beltrán, G.; Gaforio, J.J. Bioactive properties of the main triterpenes found in olives, virgin olive oil, and leaves of Olea europaea. J. Agric. Food Chem. 2013, 61, 12173-12182. [CrossRef] [PubMed]

64. Martín-García, B.; Verardo, V.; León, L.; De la Rosa, R.; Arráez-Román, D.; Segura-Carretero, A.; Gómez-Caravaca, A.M. GC-QTOF-MS as valuable tool to evaluate the influence of cultivar and sample time on olive leaves triterpenic components. Food Res. Int. 2019, 115, 219-226. [CrossRef]

65. Hsu, C.L.; Yen, G.C. Ganoderic acid and lucidenic acid (triterpenoid). In The Enzymes; Bathaie, S.Z., Tamanoi, F., Eds.; Elsevier: Amsterdam, The Netherlands, 2014; Volume 36, pp. 33-56.

66. Guinda, A.; Rada, M.; Delgado, T.; Gutiérrez-Adánez, P.; Castellano, J.M. Pentacyclic triterpenoids from olive fruit and leaf. J. Agric. Food Chem. 2010, 58, 9685-9691. [CrossRef]

67. Guinda, Á.; Castellano, J.M.; Santos-Lozano, J.M.; Delgado-Hervás, T.; Gutiérrez-Adánez, P.; Rada, M. Determination of major bioactive compounds from olive leaf. LWT-Food Sci. Technol. 2015, 64, 431-438. [CrossRef]

68. Canabarro, N.I.; Mazutti, M.A.; do Carmo Ferreira, M. Drying of olive (Olea europaea L.) leaves on a conveyor belt for supercritical extraction of bioactive compounds: Mathematical modeling of drying/extraction operations and analysis of extracts. Ind. Crop. Prod. 2019, 136, 140-151. [CrossRef]

69. Tsoumani, M.; Kontogianni, V.; Kellici, T.; Mavromoustakos, T.; Gerothanassis, I.; Tzakos, A.; Tselepis, A. Antiplatelet effect of the main triterpenoids of an olive leaf extract. Atherosclerosis 2016, 252, e1-e196. [CrossRef]

70. Duncan, S.E.; Chang, H.H. Implications of light energy on food quality and packaging selection. In Advances in Food and Nutrition Research; Henry, J., Ed.; Elsevier Inc.: Amsterdam, The Netherlands, 2012; Volume 67, pp. 25-73.

71. Mokrosnop, V.M. Functions of tocopherols in the cells of plants and other photosynthetic organisms. Ukr. Biochem. J. 2014, 86, 26-36. [CrossRef]

72. Colville, L. Seed storage. In Encyclopedia of Applied Plant Sciences, 2nd ed.; Thomas, B., Murray, B.G., Murray, D.J., Eds.; Elsevier: Oxford, UK, 2017; Volume 1, pp. 335-339.

73. Tena, N.; Lobo-Prieto, A.; Aparicio, R.; García-González, D.L. Storage and preservation of fats and oils. In Encyclopedia of Food Security and Sustainability; Ferranti, P., Berry, E.M., Anderson, J.R., Eds.; Elsevier Inc.: Amsterdam, The Netherlands, 2019; Volume 2, pp. 605-618.

74. De Lucas, A.D.; de la Ossa, E.M.; Rincón, J.; Blanco, M.A.; Gracia, I. Supercritical fluid extraction of tocopherol concentrates from olive tree leaves. J. Supercrit. Fluid. 2002, 22, 221-228. [CrossRef]

75. Botsoglou, E.; Govaris, A.; Ambrosiadis, I.; Fletouris, D. Lipid and protein oxidation of $\alpha$-linolenic acid-enriched pork during refrigerated storage as influenced by diet supplementation with olive leaves (Olea europea L.) or $\alpha$-tocopheryl acetate. Meat Sci. 2012, 92, 525-532. [CrossRef] [PubMed]

76. Tarchoune, I.; Sgherri, C.; Eddouzi, J.; Zinnai, A.; Quartacci, M.F.; Zarrouk, M. Olive leaf addition increases olive oil nutraceutical properties. Molecules 2019, 24, 545. [CrossRef] [PubMed]

77. Sudhakar, P.; Latha, P.; Reddy, P.V. Phenotyping Crop Plants for Physiological and Biochemical Traits; BS Publications: Hyderabad, India; Elsevier: Amsterdam, The Netherlands, 2016.

78. Schoefs, B. Chlorophyll and carotenoid analysis in food products. A practical case-by-case view. TrAc Trend. Anal. Chem. 2003, 22, 335-339. [CrossRef]

79. Aadil, R.M.; Roobab, U.; Sahar, A.; ur Rahman, U.; Khalil, A.A. Functionality of Bioactive Nutrients in Beverages. In Nutrients in Beverages; Grumezescu, A.M., Holban, A.M., Eds.; Elsevier Inc.: Amsterdam, The Netherlands, 2019; Volume 12, pp. 237-276.

80. Garcia-Vaquero, M.; Rajauria, G. Analytical techniques for phytochemical estimation in fruit juices. In Fruit Juices: Extraction, Composition, Quality and Analysis; Rajauria, G., Tiwari, B.K., Eds.; Elsevier: Amsterdam, The Netherlands, 2018; pp. 669-692.

81. Domonkos, I.; Kis, M.; Gombos, Z.; Ughy, B. Carotenoids, versatile components of oxygenic photosynthesis. Prog. Lipid Res. 2013, 52, 539-561. [CrossRef] [PubMed]

82. Solymosi, K.; Latruffe, N.; Morant-Manceau, A.; Schoefs, B. Food colour additives of natural origin. In Colour Additives for Foods and Beverages; Scotter, M.J., Ed.; Woodhead Publishing: Cambridge, UK, 2015; pp. 3-34. 
83. Roca, M.; Chen, K.; Pérez-Gálvez, A. Chlorophylls. In Handbook on Natural Pigments in Food and Beverages; Carle, R., Schweiggert, R.M., Eds.; Woodhead Publishing: Cambridge, UK, 2016; pp. 125-158.

84. Casida, J.E. Pest toxicology: The primary mechanisms of pesticide action. Chem. Res. Toxicol. 2009, 22, 609-619. [CrossRef]

85. Indrasti, D.; Andarwulan, N.; Purnomo, E.H.; Wulandari, N. Stability of Chlorophyll as Natural Colorant: A Review for Suji (Dracaena Angustifolia Roxb.) Leaves' Case. Curr. Res. Nutr. Food Sci. J. 2018, 6, 609-625. [CrossRef]

86. Yilmaz, C.; Gökmen, V. Chlorophyll. In Reference Module in Food Science. Encyclopedia of Food and Health; Caballero, B., Finglas, P.M., Toldrá, F., Eds.; Elsevier Inc.: Amsterdam, The Netherlands, 2016; pp. 37-41.

87. Aramrueang, N.; Asavasanti, S.; Khanunthong, A. Leafy Vegetables. In Integrated Processing Technologies for Food and Agricultural By-Products; Pan, Z., Zhang, R., Zicari, S., Eds.; Elsevier Inc.: Amsterdam, The Netherlands, 2019; pp. 245-272.

88. Trees, C.C.; Clark, D.K.; Bidigare, R.R.; Ondrusek, M.E.; Mueller, J.L. Accessory pigments versus chlorophyll a concentrations within the euphotic zone: A ubiquitous relationship. Limnol. Oceanogr. 2000, 45, 1130-1143. [CrossRef]

89. Bahloul, N.; Kechaou, N.; Mihoubi, N.B. Comparative investigation of minerals, chlorophylls contents, fatty acid composition and thermal profiles of olive leaves (Olea europeae L.) as by-product. Grasas y Aceites 2014, 65, e035. [CrossRef]

90. Brahmi, F.; Mechri, B.; Dabbou, S.; Dhibi, M.; Hammami, M. The efficacy of phenolics compounds with different polarities as antioxidants from olive leaves depending on seasonal variations. Ind. Crop Prod. 2012, 38, 146-152. [CrossRef]

91. Pokorný, J.; Korczak, J. Preparation of natural antioxidants. In Antioxidants in Food: Practical Applications, 1st ed.; Pokorný, J., Yanishlieva, N., Gordon, M., Eds.; Woodhead Publishing: Cambridge, UK, 2001; pp. 311-330.

92. Duh, P.D.; Yen, G.C. Antioxidant efficacy of methanolic extracts of peanut hulls in soybean and peanut oils. J. Am. Oil Chem. Soc. 1997, 74, 745.

93. Brglez Mojzer, E.; Knez Hrnčič, M.; Škerget, M.; Knez, Ž.; Bren, U. Polyphenols: Extraction methods, antioxidative action, bioavailability and anticarcinogenic effects. Molecules 2016, 21, 1-38. [CrossRef] [PubMed]

94. Dai, J.; Mumper, R.J. Plant phenolics: Extraction, analysis and their antioxidant and anticancer properties. Molecules 2010, 15, 7313-7352. [CrossRef]

95. Erbay, Z.; Icier, F. Optimization of hot air drying of olive leaves using response surface methodology. J. Food Eng. 2009, 91, 533-541. [CrossRef]

96. Erbay, Z.; Icier, F. Optimization of drying of olive leaves in a pilot-scale heat pump dryer. Dry. Technol. 2009, 27, 416-427. [CrossRef]

97. Nourhène, B.; Mohammed, K.; Nabil, K. Experimental and mathematical investigations of convective solar drying of four varieties of olive leaves. Food Bioprod. Process. 2008, 86, 176-184. [CrossRef]

98. Martinho, D.; Karmali, A.; Rosa, E. Extraction of Phenolic Compounds from Olive Leaf Extracts and Their Effect on Proliferation of Human Carcinoma Cell Lines. J. Agric. Sci. 2019, 10, 1271-1285. [CrossRef]

99. Babu, A.K.; Kumaresan, G.; Raj, V.A.A.; Velraj, R. Review of leaf drying: Mechanism and influencing parameters, drying methods, nutrient preservation, and mathematical models. Renew. Sustain. Energy Rev. 2018, 90, 536-556. [CrossRef]

100. Malik, N.S.; Bradford, J.M. Recovery and stability of oleuropein and other phenolic compounds during extraction and processing of olive (Olea europaea L.) leaves. J. Food Agric. Environ. 2008, 6, 8-13.

101. Ahmad-Qasem, M.H.; Barrajón-Catalán, E.; Micol, V.; Mulet, A.; García-Pérez, J.V. Influence of freezing and dehydration of olive leaves (var. Serrana) on extract composition and antioxidant potential. Food Res. Int. 2013, 50, 189-196. [CrossRef]

102. Romero-García, J.M.; Lama-Muñoz, A.; Rodríguez-Gutiérrez, G.; Moya, M.; Ruiz, E.; Fernández-Bolaños, J.; Castro, E. Obtaining sugars and natural antioxidants from olive leaves by steam-explosion. Food Chem. 2016, 210, 457-465. [CrossRef]

103. Žuntar, I.; Putnik, P.; Bursać Kovačević, D.; Nutrizio, M.; Šupljika, F.; Poljanec, A.; Dubrović, I.; Barba, F.J.; Režek Jambrak, A. Phenolic and Antioxidant Analysis of Olive Leaves Extracts (Olea europaea L.) Obtained by High Voltage Electrical Discharges (HVED). Foods 2019, 8, 1-29. [CrossRef] [PubMed] 
104. Lama-Muñoz, A.; del Mar Contreras, M.; Espínola, F.; Moya, M.; de Torres, A.; Romero, I.; Castro, E. Extraction of oleuropein and luteolin-7-O-glucoside from olive leaves: Optimization of technique and operating conditions. Food Chem. 2019, 293, 161-168. [CrossRef] [PubMed]

105. Varelis, P.; Melton, L.; Shahidi, F. Encyclopedia of Food Chemistry; Elsevier: Amsterdam, The Netherlands, 2018; Volume 1.

106. Panzella, L.; Moccia, F.; Nasti, R.; Marzorati, S.; Verotta, L.; Napolitano, A. Bioactive phenolic compounds from agri-food wastes: An update on green and sustainable extraction methodologies. Front. Nutr. 2020, 7 , 1-27. [CrossRef] [PubMed]

107. Da Rosa, G.S.; Vanga, S.K.; Gariepy, Y.; Raghavan, V. Comparison of microwave, ultrasonic and conventional techniques for extraction of bioactive compounds from olive leaves (Olea europaea L.). Innov. Food Sci. Emerg. Technol. 2019, 58, 102234. [CrossRef]

108. Sánchez-Ávila, N.; Priego-Capote, F.; Ruiz-Jiménez, J.; de Castro, M.L. Fast and selective determination of triterpenic compounds in olive leaves by liquid chromatography-tandem mass spectrometry with multiple reaction monitoring after microwave-assisted extraction. Talanta 2009, 78, 40-48. [CrossRef]

109. Mandal, S.C.; Mandal, V.; Das, A.K. Essentials of Botanical Extraction: Principles and Applications; Academic Press: Cambridge, MA, USA, 2015.

110. Baldino, L.; Della Porta, G.; Osseo, L.S.; Reverchon, E.; Adami, R. Concentrated oleuropein powder from olive leaves using alcoholic extraction and supercritical $\mathrm{CO}_{2}$ assisted extraction. J. Supercrit. Fluid. 2018, 133, 65-69. [CrossRef]

111. Le Floch, F.; Tena, M.T.; Rios, A.; Valcarcel, M. Supercritical fluid extraction of phenol compounds from olive leaves. Talanta 1998, 46, 1123-1130. [CrossRef]

112. Paulo, F.; Santos, L. Deriving valorization of phenolic compounds from olive oil by-products for food applications through microencapsulation approaches: A comprehensive review. Crit. Rev. Food Sci. Nutr. 2020, 1-26. [CrossRef]

113. Xynos, N.; Papaefstathiou, G.; Psychis, M.; Argyropoulou, A.; Aligiannis, N.; Skaltsounis, A.L. Development of a green extraction procedure with super/subcritical fluids to produce extracts enriched in oleuropein from olive leaves. J. Supercrit. Fluid. 2012, 67, 89-93. [CrossRef]

114. Pereira, R.N.; Rodrigues, R.M.; Genisheva, Z.; Oliveira, H.; de Freitas, V.; Teixeira, J.A.; Vicente, A.A. Effects of ohmic heating on extraction of food-grade phytochemicals from colored potato. LWT-Food Sci. Technol. 2016, 74, 493-503. [CrossRef]

115. Parisi, O.I.; Puoci, F.; Restuccia, D.; Farina, G.; Iemma, F.; Picci, N. Polyphenols and their formulations: Different strategies to overcome the drawbacks associated with their poor stability and bioavailability. In Polyphenols in Human Health and Disease; Watson, R.R., Preedy, V.R., Zibadi., S., Eds.; Elsevier: Amsterdam, The Netherlands, 2014; Volume 1, pp. 29-45.

116. Bishayee, A.; Ahmed, S.; Brankov, N.; Perloff, M. Triterpenoids as potential agents for the chemoprevention and therapy of breast cancer. Front. Biosci. 2011, 16, 980-996. [CrossRef] [PubMed]

117. Mourtzinos, I.; Salta, F.; Yannakopoulou, K.; Chiou, A.; Karathanos, V.T. Encapsulation of olive leaf extract in ß-cyclodextrin. J. Agric. Food Chem. 2007, 55, 8088-8094. [CrossRef] [PubMed]

118. Mohammadi, A.; Jafari, S.M.; Esfanjani, A.F.; Akhavan, S. Application of nano-encapsulated olive leaf extract in controlling the oxidative stability of soybean oil. Food Chem. 2016, 190, 513-519. [CrossRef] [PubMed]

119. Urzúa, C.; González, E.; Dueik, V.; Bouchon, P.; Giménez, B.; Robert, P. Olive leaves extract encapsulated by spray-drying in vacuum fried starch-gluten doughs. Food Bioprod. Process. 2017, 106, 171-180. [CrossRef]

120. Soleimanifar, M.; Jafari, S.M.; Assadpour, E. Encapsulation of olive leaf phenolics within electrosprayed whey protein nanoparticles; production and characterization. Food Hydrocol. 2020, 101, 105572. [CrossRef]

121. Sanchez de Medina, V.; Priego-Capote, F.; Jiménez-Ot, C.; Luque de Castro, M.D. Quality and stability of edible oils enriched with hydrophilic antioxidants from the olive tree: The role of enrichment extracts and lipid composition. J. Agric. Food Chem. 2011, 59, 11432-11441. [CrossRef]

122. Ammar, S.; Kelebek, H.; Zribi, A.; Abichou, M.; Selli, S.; Bouaziz, M. LC-DAD/ESI-MS/MS characterization of phenolic constituents in Tunisian extra-virgin olive oils: Effect of olive leaves addition on chemical composition. Food Res. Int. 2017, 100, 477-485. [CrossRef]

123. Sevim, D.; Tuncay, O.; Koseoglu, O. The effect of olive leaf addition on antioxidant content and antioxidant activity of "Memecik" olive oils at two maturity stages. J. Am. Oil Chem. Soc. 2013, 90, 1359-1369. [CrossRef] 
124. Nunes, M.A.; Pimentel, F.B.; Costa, A.S.; Alves, R.C.; Oliveira, M.B.P. Olive by-products for functional and food applications: Challenging opportunities to face environmental constraints. Innov. Food Sci. Emerg. Technol. 2016, 35, 139-148. [CrossRef]

125. Chiou, A.; Salta, F.N.; Kalogeropoulos, N.; Mylona, A.; Ntalla, I.; Andrikopoulos, N.K. Retention and distribution of polyphenols after pan-frying of French fries in oils enriched with olive leaf extract. J. Food Sci. 2007, 72, S574-S584. [CrossRef]

126. Paiva-Martins, F.; Correia, R.; Félix, S.; Ferreira, P.; Gordon, M.H. Effects of enrichment of refined olive oil with phenolic compounds from olive leaves. J. Agric. Food Chem. 2007, 55, 4139-4143. [CrossRef] [PubMed]

(C) 2020 by the authors. Licensee MDPI, Basel, Switzerland. This article is an open access article distributed under the terms and conditions of the Creative Commons Attribution (CC BY) license (http://creativecommons.org/licenses/by/4.0/). 